\title{
PENGETAHUAN PERAWAT TENTANG ELEMEN \\ DAN TAHAPAN PENGAMBILAN KEPUTUSAN
}

\author{
Rahel Juliana Benedikta Berutu
}

Email : beruturahel1507@gmail.com

\section{LATAR BELAKANG}

Suatu pelayanan kesehatan harus memiliki persyaratan pokok yang memberi pengaruh kepada masyarakat dalam menentukan pilihannya terhadap penggunanaan jasa pelayanan kesehatan. Pelayanan kesehatan yang baik adalah pelayanan kesehatan yang dapat dijangkau, mudah dicapai, tersedia di masyarakat, bermutu serta berkesinambungan. Pelayanan juga harus bersifat wajar dan dapat diterima oleh masyarakat. Ada 7 karakteristik penyedia layanan kesehatan yang diinginkan masyarakat. Ketujuh karakteristik pelayanan tersebut adalah akses, komunikasi, karakter, kualitas proses pelayanan, kesinambungan pelayanan, sarana fisik dan staf pendukung pelayanan. Pengambilan keputusan adalah suatu proses penilaian dan pemilihan dari berbagai alternatif sesuai dengan kepentingankepentingan tertentu dengan menetapkan suatu pilihan yang dianggap paling menguntungkan.

Perawat merupakan tenaga profesional yang bertanggung jawab dalam memberikan proses keperawatan kepada klien. Berdasarkan hal tersebut perawat harus mampu mengambil keputusan klinis sebagai upaya membantu pasien dalam memecahkan masalah dan menemukan jalan keluar dari seap masalah keperawatan yang dialami pasien. Perawat selalu dihadapkan dengan berbagai masalah klinis dalam memberikan perawatan terhadap pasien. Perawat yang profesional tentu saja akan mampu mengambil keputusan klinis agar masalah pasien dapat diatasi dengan cepat dan tepat. Kurangnya kemampuan perawat dalam mengambil keputusan dalam situasi yang kris tentu saja akan membahayakan pasien dan menimbulkan kerugian bagi pasien, diantaranya pasien akan terlambat untuk mendapatkan bantuan hidup, kondisi pasien akan semakin memburuk dan akibat yang paling fatal adalah kemaan.

Tingginya angka kemaan di perawatan intensif menuntut perawat untuk mengambil keputusan klinik dalam menghadapi berbagai masalah dan kasus - kasus emergensi. Sesuai dengan penelian yang dilakukan oleh Golnoosh Mirsaidi (2012) menunjukkan bahwa faktor individu yang berhubungan dengan pengambilan keputuan klinik adalah usia, jenis kelamin, latar belakang pekerjaan, unit kerja, lama kerja di unit dan status pekerjaan.

Salah satu masalah yang masih ditemukan di ruang perawatan kris adalah ngginya angka kemaan pasien. Penyebab kemaan tersebut bukan hanya disebabkan oleh rendahnya mutu pelayanan yang diberikan oleh perawat kepada pasien, akan tetapi peran perawat dalam menangani pasien dalam keadaan emergency harus dijadikan prioritas yang utama. Pihak 
manajemen tentunya harus memperhakan hal ini untuk bisa meningkatkan mutu pelayanan sehingga perawat mampu melakukan asuhan keperawatan pada kasus - kasus emergency. Oleh karena itu perawat yang mempunyai kemampuan yang cepat tanggap dalam pengambilan keputusan klinis serta mempunyai wawasan tentang ilmu - ilmu keperawatan yang terbaru sangat dibutuhkan sehingga hal ini tentunya memberikan dampak yang baik bagi kualitas asuhan keperawatan (Nursalam, 2013).

Pengambilan keputusan klinik berhubungan dengan beberapa faktor diantaranya adalah: usia, pendidikan serikat yang dimiliki perawat, lama kerja di unit dan unit tempat perawat bekerja. Penelian yang dilakukan oleh Golnoosh Mirsaidi pada tahun 2012 menunjukkan bahwa ada beberapa faktor yang berhubungan dengan pengambilan keputusan klinik diantaranya usia, jenis kelamin, latar belakang pekerjaan, unit kerja, lama kerja di unit dan status pekerjaan.

Penting bagi perawat untuk mampu mengambil keputusan klinis dengan melibatkan pasien dan keluarga dalam asuhan keperawatannya sehingka proses keperawatan yang diberikan kepada klein ini diarahkan sebagai proses refleksi baik bagi perawat ataupun klien. Pasien sebagai konsumen memiliki hak-hak yang sudah diatur dalam UU Keperawatan pasal 38 yakni pasien berhak mendapatkan informasi secara benar, jelas dan jujur tentang tindakan keperawatan yang akan dilakukan; pasien berhak meminta pendapat perawat lain dan/atau tenaga kesehatan lainnya; pasien berhak mendapatkan pelayanan keperawatan sesuai dengan kode etik, standar pelayanan keperawatan, standar profesi, standar prosedur operasional dan ketentuan peraturan perundang-undangan; pasien berhak memberi persetujuan atau penolakan tindakan keperawatan yang akan diterimanya; dan pasien berhak memperoleh keterjagaan kerahasiaan kondisi kesehatannya.

Faktor-faktor yang mempengaruhi pengambilan keputusan dalam memilih rumah sakit adalah produk, harga, promosi, tempat/place dan pengalaman sebelumnya. Produk yang 2 dimaksud yaitu pelayanan asuhan keperawatan. Tempat berupa karakteristik rumah sakit terdiri dari: aksesibilitas, dokter spesialis, kenyamanan reputasi, peralatan/teknologi modern dan tarif.

Tahap rencana keperawatan adalah menyusun rencana tindakan keperawatan yang akan dilakukan perawat untuk menangani masalah pasien sesuai dengan diagnosa keperawatan yang telah ditentukan dengan tujuan terpenuhinya kesehatan pasien. Komponen rencana keperawatan terdiri dari tujuan, kriteria hasil dan rencana tindakan keperawatan .Dalam rencana keperawatan strategi dikembangkan untuk mencegah, membatasi atau memperbaiki masalah yang ditentukan). Setiap tindakan yang akan dilakukan perawat harus dikomunikasikan baik dalam bentuk lisan maupun tertulis dan selalu menggunakan bahasa yang jelas dan tepat saat perawat mengkomunikasikan tindakan keperawatan.

Pada saat akan melakukan implementasi, perawat kontrak waktu dengan pasien dan menyampaikan serta menjelaskan apa yang akan dilakukan, tahapantahapan serta tujuan tindakan. Menjelaskan tahapan tindakan merupakan upaya meningkatkan pengetahuan pasien tentang tindakan yang akan dilakukan sehingga mampu menurunkan kegelisahan pasien dan 
menciptakan merasa aman. Perawat selalu dihadapkan dengan berbagai masalah klinis saat melakukan perawatan terhadap pasien. Pengambilan keputusan klinik keperawatan merupakan sebuah proses penilaian yang dilakukan oleh perawat seap hari terhadap proses pelayanan yang diberikan kepada pasien.

Kata kunci : Perawat, Elemen, Tahapan, Pengambilan Keputusan

\section{METODE}

Metode penulisan yang digunakan dalam penulisan laporan ini adalah literature review. Literature review yang dilakukan berupa telaah pustaka artikel penelitian. Artikel dipublikasikan secara elektronik dan diunduh melalui Google Scholar,science direct, scopus, ebook, dan dari beberapa buku keperawatan.. Kata Kunci yang digunakan yaitu Perawat, Elemen, Tahapan, Pengambilan Keputusan. Kriteria inklusi artikel adalah diterbitkan dari tahun 2012 hingga 2020, dan fulltext. Prosedur pengumpulan data yang digunakan adalah menentukan keyword untuk pencarian literatur yang relevan dengan topik kajian dan melakukan penelusuran mengenai topik relevan.

\section{HASIL}

Jurnal yang berjudul Pengambilan keputusan klinis perawat menginformasikan bahwa proses pengambilan keputusan merupakan sebuah refleksi dari perawat ataupun klien, pengambilan keputusan klinis keperawatan harus ada interaksi antara perawat-klien, pengambilan keputusan klinis keperawatan dapat dilakukan dalam setiap proses keperawatan, tugas perawat pada saat proses pengambilan keputusan ini adalah sebagai fasilitator untuk memberikan fasilitas dan dukungan pada klien, pengambilan keputusan klinis dengan melibatkan klien akan meningkatkan tingkat kemandirian bagi klien, pengambilan keputusan klinis diperlukan kemampuan berfikir kritis bagi perawat. Yang terjadi di Indonesia pengambilan keputusan belum sepenuhnya dilakukan bersama antara perawat-klien. Perawat masih berperan sebagai pengambil keputusan tunggal. Sehingga dibutuhkan pemahaman lebih lanjut terkait dengan pengambilan keputusan klinis keperawatan dengan harapan peran perawat akan lebih terlihat nyata sebagai pemberi asuhan yang akan meningkatkan kepercayaan masyarakat terhadap profesi keperawatan.

Jurnal yang berjudul Determinan Pengambilan Keputusan Klinik Keperawatan di RSUD Arifin Achmad Provinsi Riau. menunjukkan bahwa yang paling dominan berhubungan dengan pengambilan keputusan klinik keperawatan adalah faktor lama kerja. Informasi bagi perawat untuk meningkatkan kemampuan perawat dalam melakukan pengambilan keputusan klinik keperawatan, meningkatkan kompetensi perawat dan meningkatkan pengalaman kerja di unit kerjanya sehingga kualitas asuhan keperawatan yang diberikan dan mutu pelayanan rumah sakit dapat dingkatkan. Hasil penelian menunjukkan bahwa yang paling dominan berhubungan dengan pengambilan keputusan klinik keperawatan adalah faktor lama kerja.

Jurnal yang berjudul Pengaruh Empowerment Terhadap Pengambilan Keputusan Perawat menginformasikan bahwa Kemampuan membuat keputusan masalah etis menjadi salah satu persyaratan bagi perawat untuk menjalankan praktik keperawatan professional. 
Pengambilan keputusan merupakan suatu pendekatan sistematis untuk menyelesaikan suatu masalah. Salah satu strategi dalam transformasi organisasi dalam pelayanan kesehatan saat ini adalah empowerment terhadap staf. Pembagian kekuasaan (power) dengan staf dijadikan sebagai suatu strategi dalam transformasi organisasi pelayanan kesehatan.

Jurnal yang berjudul HUBUNGAN KUALITAS PELAYANAN KEPERAWATAN RAWAT INAP DENGAN PROSES PENGAMBILAN KEPUTUSAN PASIEN UNTUK MEMILIH RUMAH SAKIT menginformasikan bahwa Pelayanan yang baik adalah kemampuan seseorang dalam memberikan pelayanan yang dapat memberikan kepuasan kepada pelanggan dengan standar yang ditentukan. Dengan kualitas pelayanan yang optimal, diharapkan suatu rumah sakit akan mampu memenuhi harapan dari pasien terhadap pelayanan yang diberikan pihak rumah sakit, mampu memenangkan persaingan, dan mampu memperoleh keuntungan yang maksimal. Kualitas pelayanan itu sendiri berkaitan erat dengan kesetiaan pasien, dimana kualitas yang baik akan memberikan pengalaman bagi pelanggan dan selanjutnya akan mempengaruhi keputusan untuk datang kembali pada kunjungan perawatan berikutnya.

Jurnal yang berjudul FAKTOR-FAKTOR YANG BERHUBUNGAN DENGAN PENGAMBILAN KEPUTUSAN PERAWAT DALAM KETEPATAN TRIASE DI KOTA PADANG menginformasikan bahwa Pengambilan keputusan mengenai triase yang dilakukan oleh perawat triase sangat ditentukan oleh tingkat pengetahuan triase. Berbagai metode dapat dilakukan untuk meningkat pengetahuan perawat triase. Adanya pedoman, algoritma triase, pelatihan, kaderisasi telah membuktikan dapat meningkatkan pengetahuan triase. Pengetahuan mengenai gawat darurat dan triase dapat dicapai dengan seringnya perawat tersebut mengikuti pelatihan mengenai gawat darurat. Pelatihan yang berkelanjutan membuat ilmu mengenai triase dan gawat darurat akan berkembang sesuai dengan kemajuan dan perkembangan kebutuhan masyarakat.

\section{PEMBAHASAN}

Pengambilan keputusan yang baik dari perawat akan mendukung kualitas perawatan yang diberikan kepada pasien tetapi jika dak didukung dengan pengetahuan dan keterampilan yang baik dari perawat dalam melakukan pengambilan keputusan klinik keperawatan maka akan menurunkan mutu dan kualitas dari proses keperawatan yang diberikan kepada pasien sehingga untuk mengatasi hal tersebut peneli berpendapat perlu mengevaluasi kemampuan perawat untuk mengetahui sejauhmana pengetahuan dan keterampilan yang dimiliki perawat untuk dapat melaksanakan kerja dengan baik. Pembuatan keputusan klinik adalah hal yang sangat vital pada prakk keperawatan. Point dari pembuatan keputusan keperawatan harus memiliki dampak yang menyeluruh terhadap performa organisasi dan mampu memberikan dampak juga secara finansial. Memberikan kualitas dan pelayanan yang aman adalah tujuan dari seluruh organisasi pelayanan kesehatan. Oleh karena itu pembuatan keputusan klinik yang efekf harus benar - benar dilaksanakan (Diane L, 2018). Disarankan kepada perawat agar meningkatkan kompetensi dalam kemampuan pengambilan keputusan klinik keperawatan dengan mengiku pelahan - pelahan emergency care dan memiliki pengalaman kerja yang baik di unit kerjanya sehingga dalam mengambil keputusan klinik keperawatan 
perawat lebih profesional sehingga bisa meningkatkan kualitas pelayanan yang diberikan terutama dalam pengambilan keputusan klinik dalam proses keperawatan.

Lingkungan yang mengayomi, memberi dukungan, dan mengharapkan pengembangan kepemimpinan dapat disebut sebagai lingkungan yang empowered. Empowerment merupakan proses saat individu merasa dikuatkan, dalam pengontrolan, dan memiliki kekuasaan (power). Sumber power diklasifikasikan menjadi lima oleh French dan Raven's (French and Raven's Five Sources of Power) sebagai berikut : (Monje Amor, Abeal Vázquez, \& Faíña, 2019).

1. Reward power (Penghargaan) Reward merupakan salah sumber power yang memberikan suatu nilai. Reward dapat mempengaruhi dasar pengambilan keputusan dalam komponen pengalaman. Kekuasaan ini timbul pada diri seseorang karena ia memiliki kemampuan untuk mengendalikan sumber-daya yang dapat mempengaruhi orang lain, misalnya: ia dapat menaikkan jabatan, memberikan bonus, menaikkan gaji, atau hal-hal positif lainnya (El-demerdash \& Obied, 2016). Kekuasaan jenis ini adalah kekuasaan yang menggunakan Balas Jasa atau Reward untuk memengaruhi seseorang untuk bersedia melakukan sesuatu sesuai keinginannya. Balas jasa atau Reward dapat berupa Gaji, Upah, Bonus, Promosi, Pujian, Pengakuan ataupun penempatan tugas yang lebih menarik. Namun melalui Kekuasaan Balas jasa ini, seorang pemimpin/manajer juga dapat menunda pemberian Reward (balas jasa) tersebut sebagai hukumannya jika bawahannya tidak melakukan apa yang telah diperintahkan. Kekuasaan Balas Jasa (reward) ini timbul karena Posisi atau Jabatan seseorang yang memungkinkan dirinya memberikan penghargaan atau imbalan terhadap pekerjaan ataupun tugas yang dilakukan oleh orang lain. Salah satu penelitian menyebutkan bahwa pemberian reward berbentuk pelatihan pada perawat dapat mempengaruhi kinerja perawat rawat inap (Yurista, Bakar, \& Mirza, 2018). Penelitian lain menyebutkan bahwa pentingnya reward untuk memotivasi karyawan agar bekerja dengan baik sehingga dapat meningkatkan produktivitas dalam kinerjanya yang berdampak pada mutu pelayanan (Sri Wahyuni Yunus Kanang, 2018). Journal of Holistic Nursing Science 128

2. Coercive power (Hukuman) Coercive power merupakan salah satu sumber empowerment yang dapat mempengaruhi pengambilan keputusan dalam komponen pengalaman. Coercive power dapat berupa tindakan disiplin atau konsekuensi negatif (punishment). Kekuasaan ini timbul pada diri seseorang karena ia memiliki kemampuan untuk memberikan hukuman (akibat negatif) atau meniadakan kejadian yang positif terhadap orang lain. Pada suatu organisasi, biasanya seseorang tunduk pada atasannya karena takut dipecat, atau diturunkan dari jabatannya. Kekuasaan ini juga dapat dimiliki seseorang karena ia mempunyai informasi yang sangat penting mengenai orang lain, yang mempunyai pengaruh sangat besar terhadap orang tersebut (El-demerdash \& Obied, 2016). Berdasarkan penelitan sebelumnya pemberian punishment berpengaruh dengan kinerja dengan nilai p value 0.022 (Dhia ghoniyyah, Yuliana setyaningsih, 2013).

3. Expert power (Ahli) Empowerment dalam keperawatan dapat mempengaruhi perilaku perawat dalam mengambil keputusan. Salah satu sumber empowerment yaitu expert power yang merupakan pengetahuan, kompetensi, komunikasi dan power personal yang 
dikombinasikan dari suatu pengalaman dapat mempengaruhi dasar pengambilan keputusan dari komponen fakta dan rasional, dimana ilmu pengetahuan merupakan sesuatu yang bersumber dari fakta dan bersifat rasional. Kekuasaan Keahlian atau Expert Power ini muncul karena adanya keahlian ataupun keterampilan yang dimiliki oleh seseorang. Seringkali seseorang yang memiliki pengalaman dan keahlian tertentu memiliki kekuasaan ahli dalam suatu organisasi meskipun orang tersebut bukanlah Manajer ataupun Pemimpin. Individu-individu yang memiliki keterampilan/keahlian tersebut biasanya dipercayai oleh Manajernya untuk membimbing karyawan lainnya dengan benar (El-demerdash \& Obied, 2016). Kekuasaan ini timbul pada diri seseorang karena ia memiliki keahlian, ketrampilan atau pengetahuan khusus dalam bidangnya. Misalnya seorang ahli komputer yang bekerja pada sebuah perusahaan, atau seorang karyawan yang memiliki kemampuan menggunakan 2 atau 3 bahasa internasional, akan memiliki expert power karena sangat dibutuhkan oleh perusahaannya. Berdasarkan penelitian sebelumnya ditemukan bahwa faktor yang paling dominan mempengaruhi ketepatan pengambilan keputusan perawat adalah pengetahuan yang dimiliki oleh seorang perawat dengan nilai p value 0.012 (Khairina, Malini, Huriani, Dominan, \& Pasien, 2018).

4. Referent power (Kharisma) Salah satu sumber empowerment yang dapat mempengaruhi dasar pengambilan keputusan intuisi adalah referent yang merupakan penggunaan kharisma untuk mempengaruhi pengambilan keputusan orang lain yang melibatkan emosional individu, salah satunya adalah dengan cognitif behavioral therapy (CBT). CBT merupakan salah satu intervensi yang dapat mempengaruhi seseorang dalam melatih cara berpikir atau fungsi kognitif dan cara bertindak untuk menyelesaikan masalah. Kekuasaan ini timbul pada diri seseorang karena ia memiliki sumberdaya, kepribadian yang menarik, atau karisma tertentu. Kekuasaan ini dapat menimbulkan kekaguman pada orang tersebut, dan membuat orang yang mengaguminya ingin menjadi seperti orang tersebut. Misalnya seorang dengan kepribadian menarik, sering dijadikan contoh atau model oleh orang lain dalam Journal of Holistic Nursing Science 129 berperilaku. Berdasarkan hasil penelitian menyebutkan bahwa cognitif behavioral therapy menimbulkan efek yang positif dimana meningkatkan maturitas perilaku kerja dalam pengambilan keputusan dan harga diri perawat (Monje Amor et al., 2019). Penelitian yang lain menyebutkan bahwa kecerdasan emosi perawat dapat mempengaruhi rendahnya stress kerja yang dihadapi perawat (Yurista et al., 2018).

5. Legitimate power (Struktur Organisasi) Legitimate power adalah sumber empowerment yang datang dari karakteristik atau posisi berdasarkan pada struktur organisasi. Legitimate power dapat mempengaruhi wewenang sebagai komponen dari dasar pengambilan keputusan. Legitimate Power ini berasal dari posisi resmi yang dijabat oleh seseorang, baik itu dalam suatu organisasi, birokrasi ataupun pemerintahan. Kekuasaan Sah adalah Kekuasaan yang diperoleh dari konsekuensi hirarki dalam organisasi (Eldemerdash \& Obied, 2016). Seseorang yang menduduki posisi tertentu dalam organisasi memiliki hak dan wewenang untuk memberikan perintah dan instruksi dan mereka sebagai bawahan ataupun anggota tim berkewajiban untuk mengikuti instruksi atau perintah tersebut. Kekuasaan ini timbul pada diri seseorang karena ia memiliki posisi sebagai pejabat pada struktur organisasi formal. Orang ini memiliki kekuasaan resmi 
untuk mengendalikan dan menggunakan sumber-daya yang ada dalam organisasi. Kekuasaannya meliputi kekuatan untuk memaksa dan memberi imbalan. Anggota organisasi biasanya akan mendengarkan dan melaksanakan apa yang dikatakan oleh pemimpinnya, karena ia memiliki kekuasaan formal dalam organisasi yang dipimpinnya. Berdasarkan penelitian menyebutkan bahwa budaya organisasi berpengaruh secara signifikan terhadap motivasi kerja. Dengan adanya budaya organisasi yang positif maka motivasi berperilaku dapat dikendalikan pada arah yang positif juga (Dhia ghoniyyah, Yuliana setyaningsih, 2013).

Pengambilan keputusan adalah suatu pendekatan yang sistematis terhadap hakekat suatu masalah dengan pengumpulan fakta-fakta dan data, menentukan alternatif yang matang untuk mengambil suatu tindakan yang tepat. Ada lima hal yang perlu diperhatikan dalam pengambilan keputusan :

1. Dalam proses pengambilan keputusan tidak terjadi secara kebetulan.

2. Pengambilan keputusan tidak dilakukan secara sembrono tapi harus berdasarkan pada sistematika tertentu :

a. Tersedianya sumber-sumber untuk melaksanakan keputusan yang akan diambil.

b. Kualifikasi tenaga kerja yang tersedi,

c. Falsafah yang dianut organisasi.

d. Situasi lingkungan internal dan eksternal yang akan mempengaruhi administrasi dan manajemen di dalam organisasi.

3. Masalah harus diketahui dengan jelas.

4. Pemecahan masalah harus didasarkan pada fakta-fakta yang terkumpul dengan sistematis.

5. Keputusan yang baik adalah keputusan yang telah dipilih dari berbagai alternatif yang telah dianalisa secara matang.

Apabila pengambilan keputusan tidak didasarkan pada kelima hal diatas, akan menimbulkan berbagai masalah :

a. Tidak tepatnya keputusan.

b. Tidak terlaksananya keputusan karena tidak sesuai dengan kemampuan organisasi baik dari segi manusia, uang maupun material.

c. Ketidakmampuan pelaksana untuk bekerja karena tidak ada sinkronisasi antara kepentingan organisasi dengan orang-orang di dalam organisasi tersebut.

d. Timbulnya penolakan terhadap keputusan.

Sikap atau watak berfikir kritis dapat ditingkatkan dengan memantapkan secara positif dan memotivasi lingkungan kerja. Kreativitas penting untuk membangkitkan motivasi secara individu sehingga mampu memberikan konsep baru dengan pendekatan inovatif dalam memecahkan masalah atau isu secara fleksibel dan bebas berpikir. Keterbukaan menerima kritik akan mengakibatkan hal positif seperti; semakin terjaminnya kemampuan analisa 
seseorang terhadap fakta dan data yang dihadapi dan akan meningkatkan kemampuan untuk mengatasi kelemahan. Proses pemecahan masalah dan pengambilan keputusan seperti pada gambar di bawah ini :

Masalah

Pengumpulan Data

Analisa Data

Mengembangkan pemecahan

Memilih alternatif
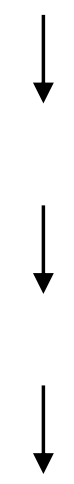

Implementasi Evaluasi

Proses pemecahan masalah dan pengambilan keputusan diatas adalah salah satu penyelesaian yang dinamis. Penyebab umum gagalnya penyelesaian masalah adalah kurang tepat mengidentifikasi masalah. Oleh karena itu identifikasi masalah adalah langkah yang paling penting. Kualitas hasil tergantung pada keakuratan dalam mengidentifikasi masalah. Identifikasi masalah dipengaruhi oleh informasi yang tersedia, nilai, sikap dan pengalaman pembuat keputusan serta waktu penyelesaian masalah. Terutama waktu yang cukup untuk mengumpulkan dan mengorganisir data. Sebagai perawat, perlu menerapkan metode berpikir secara kritis dalam mengambil keputusan. Fungsi berpikir secara kritis bagi seorang perawat adalah Dapat membedakan sejumlah penggunaan dan isu dalam keperawatan

$>$ Mengidentifikasi dan merumuskan masalah keperawatan

$>$ Menganalisis argumen dan isu- isu dalam kesimpulan dan tindakan yang dilakukan

$>$ Melaporkan data dan petunjuk yang akurat dalam keperawatan

$>$ Membuat data keperawatan yang akurat

$>$ Merumuskan dan menjelaskan nilai- nilai keputusan dalam keperawatan

Mendefinisikan Masalah Untuk mengetahui hakekat suatu masalah tidaklah mudah, karena masalah yang sebenarnya dihadapi sering terselubung dan tidak terlihat jelas. Oleh karena itu diperlukan keahlian, pendidikan dan pengalaman untuk membuat diagnosa yang tepat. Untuk itu manajer perawat dan bidan agar selalu mengembangkan kemampuannya dan belajar dari pengalaman di masa lalu untuk mempelajari perubahan yang terjadi. 
Pengumpulan Data Pengumpulan data atau informasi dikerjakan secara berkesinambungan melalui proses yang sistematis, sehingga upaya untuk mengantisipasi keadaan/masalah yang mungkin timbul akan lebih mudah dilaksanakan seperti ;

1. Apakah masalah yang dihadapi diketahui dengan jelas?

2. Apakah keadaan yang dihadapi merupakan masalah sebenarnya?

3. Apakah sistem pelaporan di dalam organisasi sudah memungkinkan untuk prediksi secara tepat?

Analisa Fakta dan Data Fakta-fakta dan data yang telah terkumpul dengan baik diolah secara sistematis yang akhirnya akan merupakan suatu informasi yang akan digunakan sebagai bahan untuk pengambilan keputusan. Analisa fakta dan data perlu dihubungkan dengan serangkaian pertanyaan sebagai berikut :

1. Situasi yang bagaimanakah yang menimbulkan masalah?

2. Apa latar belakang dari masalah?

3. Apa pengaruh dan hubungan antara masalah yang dihadapi dengan tujuan, rencana dan kebijakan organisasi?

4. Apa konsekuensi atas keputusan yang diambil?

5. Apakah pemecahan masalah sesuai dengan kapasitas organisasi?

6. Apakah waktu pengambilan tepat?

7. Siapa yang akan ditugaskan mengambil tindakan?

Penentuan Alternatif Baik buruknya sesuatu keputusan yang diambil sangat tergantung atas kemampuan menganalisa kekuatan dan kelemahan alternatif-alternatif yang dihadapi. Dalam usaha menganalisa alternatif yang ada seseorang perlu memperhitungkan :

1. Siapa yang terlibat/dipengaruhi setiap alternatif ?

2. Tindakan apa yang diperlukan ?

3. Reaksi apa yang mungkin timbul ?

4. Dimana sumber reaksi tersebut ?

5. Interaksi apa yang diperlukan?

* Penentuan Pilihan yang Terbaik Pada setiap pengambilan keputusan selalu disertai dengan pengambilan resiko. Pada umumnya pilihan diambil dari beberapa alternatif jika diduga bahwa pilihan itu akan memberikan manfaat yang paling besar baik untuk jangka panjang maupun jangka pendek. Namun demkian perlu dipertimbang juga bahwa resiko yang menyertai bersifat moderat.

* Evaluasi Untuk mengadakan penilaian yang baik, diperlukan obyektivitas dalam melakukan penilaian atau evaluasi. Biasanya suatu hal yang sangat sukar bagi seseorang untuk menilai dirinya sendiri secara obyektif. Oleh karena itu pelaksanaan penilaian dapat diserahkan kepada pihak ketiga yang tidak terlibat langsung dalam proses pengambilan keputusan untuk memperoleh tingkat obyektivitas setinggi mungkin. 


\section{PENUTUP}

\section{Kesimpulan}

pengambilan keputusan adalah suatu pendekatan yang sistematis terhadap hakekat suatu masalah yang difokuskan untuk memecahkan masalah secepatnya dimana individu harus memiliki kemampuan berfikir kritis dengan menggunakan pendidikan dan pengalaman yang berharga yang cukup efektif dalam pemecahan masalah. Dalam pengambilan keputusan perawat harus mempertimbangkan segala aspek, baik dari pasien itu sendiri, keluarga pasien, tenaga kesehatan lain, dan psiko, sosial, dan cultural yang diterapkan, Perawat juga harus ikut membantu klien ataupun keluarga klien dalam mengambil keputusan yang berhubungan dengan kesehatan klien. Oleh sebab itu sangat penting untuk perawat dalam belajar dan memahami bagaimana mengambil keputusan yang tepat dan tidak melanggar etika profesi keperawatan diikuti konsep berfikir kritis yang sudah dimiliki perawat itu sendiri.

\section{Saran}

Sebagai perawat harus memahami suatu penyakit dari sudut medik maupun keperawatan adalah hal yang mutlak sebelum berhadapan dengan berbagai macam kasus. Oleh sebab itu baik sekali bila perawat menumbuhkan minat baca untuk menambah wawasan. Perawat juga harus mampu menemukan masalah-masalah yang sungguh-sungguh terjadi pada klien untuk menegakkan suatu diagnosa keperawatan yang memerlukan penanganan segera.

\section{DAFTAR PUSTAKA}

Erawantini, F. \& Wibowo, N. S. 2019. Implementasi Rekam Medis Elektronik dengan Sistem Pendukung Keputusan Klinis. Jurnal Teknologi dan Terapan.6(2): 75-78.

Erniati,S., Machmud, R., Haramawati. (2019). Determinant Of Nursing Clinical Decision Making In Arifin Achmad GeneralHospitalOf Riau Province Determinan Pengambilan Keputusan Klinik Keperawatan di RSUD Arifin Achmad Provinsi Riau. JURNAL KESEHATAN KOMUNITAS ( JOURNAL OF COMMUNITY HEALT H ) KESKOM. 2019;5(3) : 227-234. Received 11 November 2019 Accepted 16 Desember 2019 p - ISSN : 2088-7612 e - ISSN : 2548-8538 DOI: hps://doi.org/10.25311/keskom.Vol5.Iss3.464

Deniati, dkk. (2018). Pengaruh Berfikir Kritis Terhadap Kemampuan Perawat Pelaksana Dalam Melakukan Asuhan Keperawatan di Rumah Sakit Hermina Bekasi Tahun 2016. Jurnal Kesehatan Holistik, 12(1), 21-24 
Faidah, N., Ratnawaty, R., Setyoadi. (2013). Pengalaman Perawat dalam Pengambilan Keputusan Triage di Instalasi Gawat Darurat RSUD RAA. Soewondo Pati. Jurnal

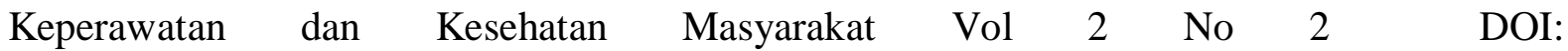
https://doi.org/10.31596/jcu.v1i2.32

Khairina, I., Malini, H., Huriani, E. (2018). FAKTOR-FAKTOR YANG BERHUBUNGAN DENGAN PENGAMBILAN KEPUTUSAN PERAWAT DALAM KETEPATAN TRIASE DI KOTA PADANG. Indonesian Journal for Health Sciences Vol.02, No.01, Maret 2018, Hal 1-6 ISSN 2549-2721 (Print), ISSN 2549-2748 (Online)

Mariana,D.(2019). HUBUNGAN KUALITAS PELAYANAN KEPERAWATAN RAWAT INAP DENGAN PROSES PENGAMBILAN KEPUTUSAN PASIEN UNTUK MEMILIH RUMAH SAKIT. Jurnal Ilmiah Multi Science Kesehatan Volume 10, Juni 2019, Nomor 2

Masruroh H, Joko P, Abdul G. (2014). Buku pedoman keperawatan. Yogyakarta: Indoliterasi.

Pahar, I., Dwiantoro, L.(2020).Pengaruh Empowerment Terhadap Pengambilan Keputusan Perawat: Kajian Literature Review. JOURNAL OF HOLISTIC NURSING SCIENCE Vol. 7 No. 2 (2020) pp. 124-132 p-ISSN: 2579-8472 e-ISSN: 2579-7751

Rahayu, C., Mulyani, S .(2020). PENGAMBILAN KEPUTUSAN KLINIS PERAWAT. Jurnal Ilmiah Kesehatan, Vol. 10, No 1, pp. 1-11, May 2020.

Simamora, R. H. (2005). Hubungan Persepsi Perawat Pelaksana Terhadap Penerapan Fungsi Pengorganisasian Yang Dilakukan Oleh Kepala Ruangan Dengan Kinerjanya Diruang Rawat Inap RSUD Koja Jakarta Utara (Doctoral dissertation, Tesis FIK UI, Tidakdipublikasikan).

Simamora, R. H. (2019). Menjadiperawat yang: CIH'HUY. Surakarta: Kekata Publisher.

Touwe, F. R., dkk. 2019. Pemanfatan Rekam Medis sebagai Sumber Informasi Untuk Pengambilan Keputusan di RuangRawat Inap RSI Faisal Makassar. Jurnal Mitra sehat. 9(2): 540-551 